\title{
A Review of Servitization Theoretical Foundations
}

\author{
Agustín Ruiz-Martín (DD, Eloísa Díaz-Garrido (D) \\ Rey Juan Carlos University (Spain) \\ agustin.ruiz@urjc.es,eloisa.diaz@urjc.es
}

Received: December 2020

Accepted: March 2021

\begin{abstract}
:
Purpose: This study seeks to analyse how the servitization topic has been addressed through different theoretical approaches. More specifically, the aim is to answer two key questions: What theoretical approaches have been used to study the phenomenon of servitization? What specific aspects of the servitization process have been analysed through each theoretical approach?

Design/methodology/approach: This paper adopts a systematic literature review. The first step involves a descriptive analysis, which is then followed by a thematic one.

Findings: The results show that the topic of servitization has been analysed according to the main boundary of the firm theories (Resource-based view, Game theory, and Transaction cost economics) and to organizational boundaries (Contingency theory and Resource dependence theory), among others. From the perspective of these theoretical frameworks, the following topics have received the most scholarly attention: Performance, Capabilities, Supply Chain Management, Business Model, Strategy, and Sustainability.
\end{abstract}

Originality/value: Observations are made on the relevance that diverse theories have on the development of research into servitization. The most suitable theoretical lenses are recommended for future research.

Keywords: servitization, organisational boundary theory, boundary of the firm theory, systematic literature review

\section{To cite this article:}

Ruiz-Martín, A., \& Díaz-Garrido, E. (2021). A review of servitization theoretical foundations. Journal of Industrial Engineering and Management, 14(3), 496-519. https://doi.org/10.3926/jiem.3466

\section{Introduction}

The last twenty years have witnessed major technological advances that together with the freeing up of global trade have led to increased competition in the manufacturing sector. This sharp increase in competition has prompted the relocation, or even closure, of many western industrial firms due to the lower labour costs in other countries (mainly in Asia). Faced with this increase in competition, manufacturing firms have now been forced to reinvent themselves, and many have seized the business opportunity involved in launching the process of marketing services alongside their products (Johnson, Herrmann \& Bauer, 1999).

Vandermerwe and Rada (1988) have referred to this process as servitization, which may be understood as a process for increasing value by adding services to products. It is a way of creating value-added capabilities that are 
distinctive and sustainable regarding competitors (Baines, Lightfoot, Benedettini \& Kay, 2009a), whereby instead of simply providing products, a firm begins marketing product-service systems (PSS) (Visnjic \& Van Looy, 2013). In short, servitization is when manufacturing firms provide their customers with a comprehensive range of products and services in order to increase the latter's user value and experience.

The literature has analysed the servitization process from different angles (Forkmann, Henneberg, Witell \& Kindström, 2017). It is a complex, contingent and even paradoxical issue that involves myriad organizational, operational, strategic, relational and even ecosystemic issues. Given this complexity and the considerable increase in the number of publications on this transition process, recent studies have focused on the need to strengthen the theories related to the servitization process (Rabetino, Harmsen, Kohtamäki \& Sihvonen, 2018; Raddats, Kowalkowski, Benedettini, Burton \& Gebauer, 2019).

Gioia and Pitre (1990), for example, have defined theory-building as "any coherent description or explanation of observed or experienced phenomena". Bacharach (1989) considers a theory to be "a statement of relations among concepts within a set of boundary assumptions and constraints. It is no more than a linguistic device used to organize a complex empirical world". Theories help researchers to make sense of the world around us. Over and above a mere description, theories allow predicting the nature of relationships between phenomena. In turn, phenomena of interest uncover topics of practical significance. Theories sometimes arise from a new idea or a metaphor that leads to the development of a conceptual model that then helps to reconsider theoretical approaches, being referred to as "theory building" (Colquitt \& Zapata-Phelan, 2007). On other occasions, previously established theories are applied within a new context to help to understand a topic, which is known as "theory testing".

Within the field of servitization, there is a need for more studies on both theory building and theory testing. Rabetino et al. (2018) and Eloranta and Turunen (2015) consider the need to extend and develop this research topic using well-established theories and theoretical frameworks from different disciplines. Li, Kumar, Claes and Found (2020) have expressed the need to study social and organizational theories, calling for the increased use of well-established ones from mature fields and borrowing ideas to stimulate knowledge accumulation.

The purpose of this research is to study how the topic of servitization has been analysed through different theoretical approaches. The specific aim is to answer two key questions: (1) What theoretical approaches have been used to study the phenomenon of servitization? (2) What specific aspects of the servitization process have been analysed by each theoretical approach?

We shall be using a systematic review of the literature to answer these two questions. The first step will involve using a descriptive analysis to find all those articles published on servitization that are related to one or more of the theoretical approaches, and the second step will consist of a thematic analysis of the main topics studied in the selected articles.

This review helps to identify the theoretical lens that best explains the phenomenon of servitization, revealing its strategic importance and the need for an organizational aspects-servitization-performance fit. In addition, it also highlights the two main challenges that industrial firms must face: digitalization and the natural environment.

The paper is organised into three clearly differentiated sections. The first one describes the methodology, specifically identifying the keywords used in the search and the criteria applied for the systematic literature review, as well as the papers that comprise the sample and their subsequent screening. The following section will involve studying the results based on the papers obtained in two clearly differentiated analyses: one descriptive and the other thematic. Finally, the third section summarises the conclusions, outlining this study's contributions and limitations.

\section{Methodology}

Answering our two questions has involved conducting a systematic two-stage review of the literature, beginning with a descriptive analysis based on activity indicators and then proceeding with a thematic analysis (Tranfield, Denyer \& Smart, 2003). 
The review's first step requires identifying and selecting the data to be used. Again according to Ramos-Rodríguez and Ruiz-Navarro (2004), the data sources are papers published in scientific journals, as their content is deemed to be "certified knowledge" (this term is commonly used to describe those papers that have successfully undergone a critical peer review).

In particular, Elsevier's Scopus database has been used to find the papers because it is the most comprehensive electronic database for citations and abstracts (it provides $20 \%$ more coverage than Web of Science) and has more consistent results (Falagas, Pitsouni, Malietzis \& Pappas, 2008). Moreover, Scopus is considered as an effective tool for electronic literature search, which has bed evidenced by Tukker (2015) or Li et al. (2020) in their revisions. The decision to choose scientific papers rather than other documentary sources, such as books, PhD theses or congress proceedings, is based on their consideration as certified knowledge, being understood as research that has been submitted to peer review and successfully passed their critical evaluation (Callon, Courtial \& Penan, 1993).

The identification of the pertinent papers for conducting our research has involved the use of a search string consisting of terms related to the servitization process and each one of the theoretical approaches to be studied. The keywords have been chosen according to the study by Rabetino et al. (2018), involving some of the primary search terms used in their research. The timeframe for the search has extended from 1988, the publication year of the paper by Vandermerwe and Rada (1988), which first referred to the transformation process under study here as servitization, through to December 2020. Table 1 lists the terms used, the search conditions established, and the papers found.

This initial search produced 117 papers. This was followed by an analysis of these papers' abstracts and keywords to discover whether they were sufficiently relevant to PSS. Three papers were discarded from Scientific management theory because they had not been published in journals, but in conference proceedings instead. A further 24 papers were discarded for not being considered relevant, more specifically because they did not relate to industrial companies although they did relate to services. Out of these latter papers, four corresponded to Game theory, one to Industrial organization, eleven to Linear programming, two to Resource-based, three to Organizational behavior, and three to Scientific management. After screening, there were 93 papers in the final sample. The list of papers analysed is provided in Appendix A. Figure 1 illustrates the review process we have conducted.

\begin{tabular}{|l|l|}
\hline Servitization & \multicolumn{1}{|c|}{ Search tips and limits } \\
& $\begin{array}{l}\text { serviti* OR servicing OR "product-service } \\
\text { systems" OR "integration of products and } \\
\text { services" OR "service growth" OR "service } \\
\text { transition" OR "service science" OR } \\
\text { "integrated solution" OR "solution offering" } \\
\text { OR "service infusion"... } \\
\text { Limit: } \\
\text { Article title, Abstract, Keywords } \\
\text { Published between } 1998 \text { and } 2020 \\
\text { Document type: paper } \\
\text { Search conducted between January and } \\
\text { December 2020 (final check on 15/12/2020) }\end{array}$ \\
\hline Servitization + theory & \multicolumn{1}{|c|}{ Search strings and results } \\
\hline Agency theory & $\ldots$ AND "agency theory" \\
\hline Bureaucracy theory & Three papers found \\
\hline Contingency theory & $\ldots$ AND "bureaucracy theory" \\
& No papers found \\
\hline Elements administration & $\ldots$ AND "contingency theory" \\
& Ten papers found \\
\hline & $\begin{array}{l}\text { AND "elements administration" } \\
\text { No papers found }\end{array}$ \\
\hline
\end{tabular}




\begin{tabular}{|c|c|}
\hline Servitization + theory & Search strings and results \\
\hline Ecological theory & $\begin{array}{l}\ldots \text { AND "ecological theory" } \\
\text { One paper found }\end{array}$ \\
\hline Administrative behavior & $\begin{array}{l}\ldots \text { AND "Fatalism" } \\
\text { No papers found }\end{array}$ \\
\hline Game theory & $\begin{array}{l}\ldots \text { AND "game theory" } \\
\text { Twenty papers found }\end{array}$ \\
\hline Human relations theory & $\begin{array}{l}\text {... AND "human relations theory" } \\
\text { No papers found }\end{array}$ \\
\hline Industrial organization & $\begin{array}{l}\text {... AND "industrial organization" } \\
\text { Five papers found }\end{array}$ \\
\hline Institutional theory & $\begin{array}{l}\text {... AND "institutional theory" } \\
\text { Three papers found }\end{array}$ \\
\hline Linear programming & $\begin{array}{l}\text {... AND "Linear programming" } \\
\text { Fourteen papers found }\end{array}$ \\
\hline Organizational behavior & $\begin{array}{l}\text {... AND "organizational behavior" } \\
\text { Six papers found }\end{array}$ \\
\hline Resource-based theory & $\begin{array}{l}\ldots \text { AND "resource-based" } \\
\text { Thirty one papers found }\end{array}$ \\
\hline Resource dependence theory & $\begin{array}{l}\ldots \text { AND "resource dependence" } \\
\text { Four papers found }\end{array}$ \\
\hline Scientific management & $\begin{array}{l}\text {... AND "scientific management" } \\
\text { Five papers found }\end{array}$ \\
\hline Social practice theory & $\begin{array}{l}\ldots \text { AND "social practice theory" } \\
\text { Four papers found }\end{array}$ \\
\hline Transaction cost & $\begin{array}{l}\ldots \text { AND "transaction cost" } \\
\text { Eleven papers found }\end{array}$ \\
\hline
\end{tabular}

Table 1. Selection criteria and keywords

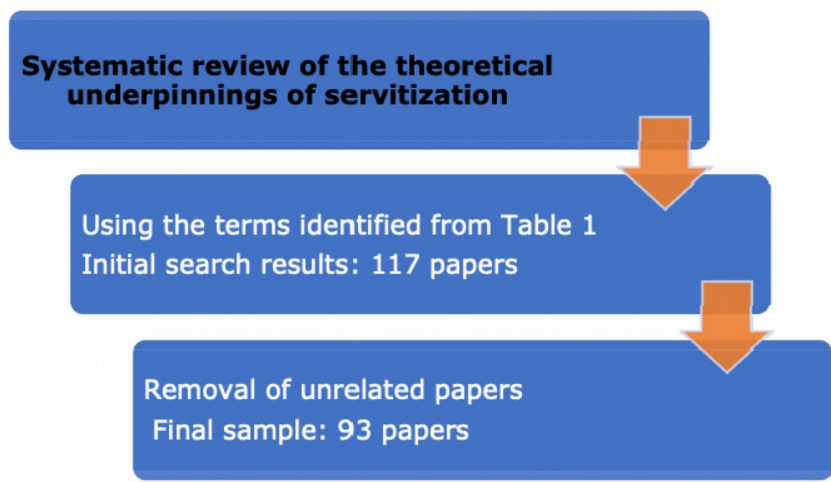

Figure 1. The review process 


\section{Findings}

The sample's 93 papers have been used to conduct a descriptive analysis of the following indicators of size: the journals in which they were published and their authors.

The 93 papers have been published in 58 different journals. As an overview, Table 2 below lists those journals that have published three or more papers.

\begin{tabular}{|c|c|c|c|}
\hline Journal & No. papers & Theory & Frequency \\
\hline \multirow{4}{*}{ Industrial Marketing Management } & \multirow{4}{*}{6} & Agency & 1 \\
\hline & & Resource-based & 3 \\
\hline & & Industrial organization & 1 \\
\hline & & Institutional & 1 \\
\hline \multirow{2}{*}{ Journal of Business and Industrial Marketing } & \multirow{2}{*}{5} & Resource-based & 4 \\
\hline & & Transaction cost & 1 \\
\hline \multirow{3}{*}{ Journal of Cleaner Production } & \multirow{3}{*}{5} & Transaction cost & 2 \\
\hline & & Institutional & 1 \\
\hline & & Social practice & 2 \\
\hline \multirow{3}{*}{ International Journal of Production Economics } & \multirow{3}{*}{5} & Game & 1 \\
\hline & & Contingency & 1 \\
\hline & & Resource-based & 3 \\
\hline \multirow{3}{*}{ International Journal of Production Research } & \multirow{3}{*}{3} & Game & 1 \\
\hline & & Ecological & 1 \\
\hline & & Linear programming & 1 \\
\hline \multirow{2}{*}{ International Journal of Operations and Production Management } & \multirow{2}{*}{3} & Contingency & 2 \\
\hline & & Organizational behavior & 1 \\
\hline
\end{tabular}

Table 2. Journals with three or more publications (author's own work)

Among these six journals, International Journal of Production Economics, International Journal of Operations and Production Management and International Journal of Production Research publish papers related to the topics of engineering, production and management. In turn, the papers published in Journal of Business and Industrial Marketing and Industrial Marketing Management are more closely related to industrial marketing and management. Finally, Journal of Cleaner Production is an interdisciplinary publication that focuses on Cleaner Production.

The six journals featured in Table 2 are ranked in percentile 1 in CiteScore 2019, with the exception of one of the topics (Business, Management and Accounting-Marketing) in Journal of Business and Industrial Marketing, which is ranked in percentile 2 .

As is the case with the journals, there is a broad range of authorship for the papers in the sample. Specifically, only nine scholars have published two or more of the papers (Table 3).

As regards the authors publishing the most on the topic under study here, first place corresponds to Asian scholars, and this is due to the sharp increase in publications that have been written in China on the subject of servitization, which stands to reason because that country today records the world's highest industrial output. On the other hand, the table features scholars such as Baines, Gebauer, Parida and Kohtamäki, who are leading authorities in servitization-based research. These results are consistent with those reported by Martín-Peña, Pinillos and Reyes (2017) and Rabetino et al. (2018). 


\begin{tabular}{|l|c|}
\hline \multicolumn{1}{|c|}{ Authors } & Frequency \\
\hline Chang, C-Y & 3 \\
\hline Cheng, T.C.E & 2 \\
\hline Chang, F. & 2 \\
\hline Baines, T. & 2 \\
\hline Chicksand, D. & 2 \\
\hline Gebauer, H. & 2 \\
\hline Kohtamäki, M. & 2 \\
\hline Parida, V. & 2 \\
\hline Lin, L. & 2 \\
\hline
\end{tabular}

Table 3. Authors with two or more publications

This descriptive analysis concludes with Figure 2, which lists the year of issue of the papers analysed.

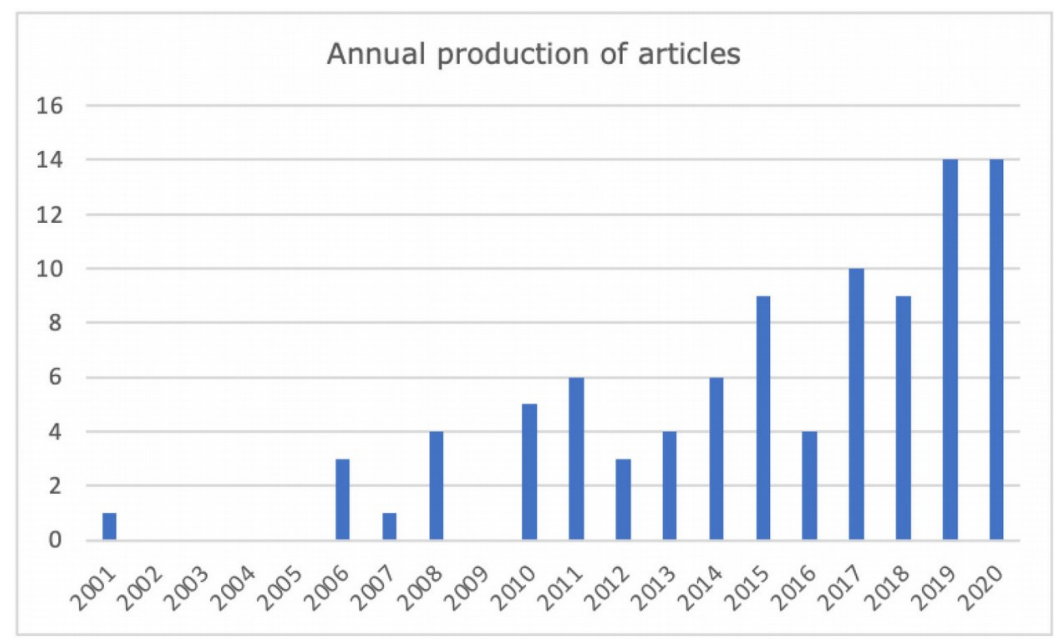

Figure 2. Annual production of articles

Most of the papers on servitization, together with the different theoretical frameworks underpinning them, have been published in the past 20 years. These results are consistent with those reported in prior studies, such as those by Díaz-Garrido, Pinillos, Soriano-Pinar and García-Magro (2018), Rabetino et al. (2018), and Li et al. (2020), which reveal an exponential increase in the number of publications dealing with servitization.

\section{Discussion of Results}

The review of the papers analysed reveals that the following theories have underpinned the subject of servitization over the past 32 years: Resource-based theory, Game theory, Transaction cost theory, Contingency theory, Resource dependence, Social practice theory, Linear programming, Organizational behavior, Agency theory, Scientific management, Industrial organization, and Ecological theory. Table 4 details the number of papers that have been analysed for each one of these theoretical approaches. By contrast, the topic of servitization has not been addressed through other theoretical approaches, such as Bureaucracy theory, Elements administration, Administrative behavior, and Human relations theory. There are some papers in which aspects of servitization have been addressed by two or more theories, such as those by Ceci and Prencipe (2008), Ceci and Masini (2011), Yan, Li and Cheng (2020) (Contingency theory and Resource-based theory); Chang, Zhou, Zhang, Xiao and Wang (2019) (Resource dependence and Game theory) or Kohtamäki, Parida, Oghazi, Gebauer and Baines (2019), Zhang, Wang, Gao and Li (2019) (Transaction cost and Resource-based theory). 
All these theoretical approaches may be divided into two main groups: boundary of the firm and organizational boundary theories, on the basis that economics is dedicated to the study of the way in which players may choose to use their scarce resources with different applications. It may therefore be stated that economics (seen from a classical viewpoint, and originating in British marginalism through Jevons, the Austrian school by the hand of Menger, and Walras for the development of general equilibrium theory) is the source of the different approaches that make up boundary of the firm theories, and which seeks to explain why firms exist and the nature of their relationship with the market. On the other hand, organizational boundary theories provide the foundations for the organizational design of any kind of institution (public or private, for-profit and not-for-profit) (Table 4). To answer the first question initially posed, the results show that servitization has basically been underpinned by the following four theoretical approaches: Resource based, Game theory, Transaction cost, and Contingency theory, as these account for around $71 \%$ of the papers studied (Table 4 ).

\begin{tabular}{|c|c|c|c|c|}
\hline & $\begin{array}{l}\text { THEORETICAL } \\
\text { APPROACHES }\end{array}$ & $\begin{array}{l}\text { No. Papers } \\
\text { found }\end{array}$ & $\begin{array}{c}\text { No. } \\
\text { Papers } \\
\text { analysed } \\
\end{array}$ & $\begin{array}{c}\text { Frequency } \\
\%\end{array}$ \\
\hline & Resource-based & 31 & 29 & 31.18 \\
\hline \multirow{6}{*}{$\begin{array}{l}\text { Boundary of the } \\
\text { firm theories }\end{array}$} & Game & 20 & 16 & 17.20 \\
\hline & 'Transaction cost & 11 & 11 & 11.83 \\
\hline & Contingency & 10 & 10 & 10.75 \\
\hline & Industrial organization & 5 & 4 & 4.30 \\
\hline & Social practice & 4 & 4 & 4.30 \\
\hline & Linear programming & 14 & 3 & 3.23 \\
\hline \multirow{6}{*}{$\begin{array}{l}\text { Organizational } \\
\text { boundary theories }\end{array}$} & Organizational behavior & 6 & 3 & 3.23 \\
\hline & Resource dependence & 4 & 4 & 4.30 \\
\hline & Institutional & 3 & 3 & 3.23 \\
\hline & Agency & 3 & 3 & 3.23 \\
\hline & Scientific management & 5 & 2 & 2.15 \\
\hline & Ecological & 1 & 1 & 1.08 \\
\hline
\end{tabular}

Table 4. Theoretical Approaches and servitization

Resource-based theory argues that differences between firms are primarily the result of firm heterogeneity regarding their bundles of resource and capability endowments (Barney, 1991; Rumelt, 1984; Wernerfelt, 1984). This theory contends that firms are capable of creating and upholding competitive advantages through the development and integration of a series of valuable, rare and inimitable resources. This theory has provided the theoretical underpinnings for a large number of the papers analysed (31.18\%). This is in keeping with other prior studies in which this theory serves as a platform for many literature discussions focusing on service infusion (Oliva \& Kallenberg, 2003).

The subject of servitization analysed through Resource-based theory refers to assets that are valuable, rare, inimitable, or organised (VRIO) (Eloranta \& Turunen, 2015). As regards the resources and capabilities related to servitization, the literature has identified three main resources and potentially capabilities: installed base (e.g., Oliva \& Kallenberg, 2003; Ulaga \& Reinartz, 2011; Wise \& Baumgartner, 1999), unique and complex ranges (e.g., Ulaga \& Reinartz, 2011; Gremyr, Löfberg \& Witell, 2010), and improved services-relationships (e.g., Tuli, Kohli \& Bharadwaj, 2007). Furthermore, the services added to the product range may be considered a resource, providing financial value (Kohtamäki, Partanen, Parida \& Wincent, 2013) and driving innovation (Wallin, Parida \& Isaksson, 2015). As regards capabilities, the unique ones related to servitization have also been singled out (e.g., Gebauer \& Fleisch, 2007; Storbacka, 2011), as has the role played by complex combinations of resources and capabilities in 
avoiding imitation (Oliveira \& Roth, 2012). Kanninen, Penttinen, Tinnilä and Kaario (2017) have analysed the type of capabilities firms in industry require as servitization spreads.

Resource-based theory has provided the reference framework for studies that analyse servitization through digitalization (Coreynen, Matthyssens \& Van Bockhaven, 2017), as well as for deciding the service strategy and growth options that may be most appropriate and successful, considering the resources required in each case (Raddats, Burton, \& Ashman, 2015; Raddats \& Easingwood, 2010).

Game theory has been used in $17.20 \%$ of the papers analysed. This is a discipline that was launched by Von Neumann, Morgenstern \& Kuhn (1944) based on the transcription of a situation into abstract formulations based on logics and rules assuming rational behavior. Generally speaking, it can be classified into non-cooperative and cooperative game approaches (Song \& Panayides, 2002).

This theoretical approach is used to analyse the return on the servitization strategy (Lee; Yoo \& Kim, 2016). Zhong (2014) adopts Game theory for conducting a quantitative analysis of coordination mechanisms for integrating products and services through the creation of mathematical models. It is also an ideal theoretical model for analysing the relationships between consumers and service providers (Hsieh \& Yeh, 2018). Hezarkhani (2017) uses Game theory to manage these relationships, seeking to coordinate the parties' efforts to optimise the gains made by the entire system, instead of focusing on the decision-making problems they face. Gómez \& Heredero (2013) consider that gamification leads to an improvement in users' experience, pursuing the aim of motivating, achieving, promoting and upholding greater engagement with the features of the products and services that firms offer them. This renders it expedient to consider that Game theory is a useful framework for analysing consumers' behavior in the provision of services and the impact of the co-creation of value between businesses and consumers. Lee et al. (2016) use Game theory to identify the situations in which a servitization strategy is more profitable (depending both on the degree of dependence between the service being provided and the tangible assets and on the operation of the retail channel).

The origin of Transaction cost theory, which is a feature of $11.83 \%$ of the papers analysed, has been attributed to Coase (1937), who reported that the existence of firms lies in the fact that markets operate with certain costs, as well as being imperfect. These so-called transaction costs reflect the market's operating costs. According to this neoclassical approach, prices in a perfectly competitive market contain all the information to ensure the exchange can take place. According to Transaction cost theory, the pricing system is costly, which explains the existence of organizations; in turn, the coexistence of markets and organizations is explained by the characteristics associated with the different types of transaction, which refer to the information and nature of the goods being exchanged (Williamson, 1977).

Transaction cost theory has acted as a yardstick for analysing new business models when applying servitization processes in general (Mont, Dalhammar \& Jacobsson, 2006) or new business models involving territorial servitization (Bellandi \& Santini, 2019). It has also provided the basis for sundry studies related to digital servitization. Nevertheless, Kohtamäki et al. (2019) consider that transaction costs can be significant in the provision of product-service-software systems because of the sale and delivery of highly complex, bespoke smart solutions. Delivering smart solutions also incurs significant transaction costs because of upstream interactions with the service supply chain, in addition to product supply. Likewise, an analysis has been conducted from a transaction cost perspective to understand how supply chains are organised regarding relations involving suppliers, manufacturers, and providers in the field of servitization (Boehmer, Shukla, Kapletia \& Tiwari, 2020; Wiig, 2001) All the factors commonly associated with influencing transaction costs (asset specificity, uncertainty and frequency) are significantly higher for firms with more fully implemented supply chain management, making a more integrated solution advantageous (Lietke \& Boslau, 2007).

Contingency theory has been used in $10.75 \%$ of the papers. Walker, Chicksand, Radnor and Watson (2015) consider it a suitable theory for explaining the topic of servitization. This theory postulates a link between the environment, organizational structure and performance (Drazin \& Van de Ven, 1985; Duncan, 1972; Venkatraman, 1989). According to this theoretical approach, it is argued that a strategy is successful only when there is a fit (i.e., a degree of internal consistency) between existing capabilities and external environmental contingencies 
(Venkatraman, 1989). This interpretation of fit may be used to obtain the configurations of different contingencies, each one with distinctive implications for organizational design (Child, 1975). A direct implication of the contingent approach for the study of servitization is that, as such, there is no better strategy when addressing a servitization process in an industrial firm.

Yan et al. (2020) merge Contingency theory with Resource-based theory to analyse the success of servitization in companies based on two factors of organizational design: a service-focused organizational structure and a service-focused organizational culture. Ceci \& Prencipe (2008) investigate the way in which the environmental context and companies' organizational structure influence their strategic choice and lead to different configurations of capabilities. In a similar vein, Ceci and Masini (2011) apply these same theories to analyse how the differences in fit between environmental variables and strategic choices partially account for performance differences among integrated solution providers.

The results show that the topic of servitization has not been addressed through other theoretical approaches, such as Bureaucracy theory, Elements administration, Administrative behavior, and Human relations theory. These are classic theoretical approaches within Organizational boundary theories, with a clear pragmatic orientation focused on worker analysis: job design, productivity, behavior, ...

To answer the second question and identify those specific aspects of the servitization process that have been analysed through each one of these theoretical approaches, this research has been informed by research topics identified in the study by Li et al. (2020): Organizational aspects, Value co-creation, Consumer behavior, Business models, Resources and capabilities, Innovation, Performance, Sustainability, Supply chain management. A few more have been added, such as the following: digitalization, Industry 4.0, Circular economy, Human resource management, and CRM. The data on the frequency with which each topic has been addressed are contained in the following table (Table 5).

\begin{tabular}{|l|c|c|c|c|c|}
\hline \multicolumn{1}{|c|}{ Research topics } & Total & $\begin{array}{c}\text { Organizational } \\
\text { theories }\end{array}$ & $\begin{array}{c}\text { Theories of } \\
\text { the firm }\end{array}$ & Frequency & $\begin{array}{c}\text { Aggregate } \\
\text { frequency }\end{array}$ \\
\hline Performance & 20 & 6 & 14 & 21.51 & 21.51 \\
\hline Capabilities & 15 & 3 & 12 & 16.13 & 37.63 \\
\hline Business models & 10 & 1 & 9 & 10.75 & 48.39 \\
\hline Supply chain management & 8 & 3 & 5 & 8.60 & 56.99 \\
\hline Strategy & 6 & 2 & 4 & 6.45 & 63.44 \\
\hline Sustainability & 6 & 2 & 4 & 6.45 & 69.89 \\
\hline Consumer behavior & 5 & 1 & 4 & 5.38 & 75.27 \\
\hline Value co-creation & 4 & 3 & 1 & 4.30 & 79.57 \\
\hline Organizational aspects & 3 & 2 & 1 & 3.23 & 82.80 \\
\hline Innovation & 3 & 0 & 3 & 3.23 & 86.02 \\
\hline Flexibility & 3 & 1 & 2 & 3.23 & 89.25 \\
\hline Digitization & 3 & 2 & 1 & 3.23 & 92.47 \\
\hline Circular economy & 2 & 2 & 0 & 2.15 & 94.62 \\
\hline Human resources & 2 & 1 & 1 & 2.15 & 96.77 \\
\hline Industry 4.0 & 2 & 0 & 2 & 2.15 & 98.92 \\
\hline Customer relationship management & 1 & 0 & 1 & 1.08 & 100.00 \\
\hline
\end{tabular}

Table 5. Research topics in the theoretical underpinnings of servitization

The research topic that most frequently appears in the papers analysed involves performance $(21.51 \%)$, which is studied from the perspective of different theories, such as Contingency theory (Ceci \& Masini, 2011), Linear programming (Geng, Chu, Xue \& Zhang, 2011), Resource dependence theory (Shah, Jajja, Chatha \& Farooq, 2020; 
Chang et al., 2019), Agency theory (Datta, 2020), Game theory (Arabi, Mansour \& Shokouhyar, 2018; Gómez \& Heredero, 2013; Hezarkhani, 2017; Lee et al., 2016) and Resource-based theory (Fang, Palmatier \& Steenkamp, 2008; Yan et al., 2020; Zhang et al., 2019), These results are consistent with those reported by Wang, Lai, and Shou (2018), identifying numerous studies that analyse the impact that servitization has on performance.

The literature has traditionally analysed a service-based strategy as a source of competitive advantage in goods manufacturing firms (Wise \& Baumgartner, 1999), and which furthermore enable those firms defining it to enhance their performances (Neu \& Brown, 2005). Nevertheless, servitization does not always have positive outcomes, which leads to the consideration of what is referred to as the "service paradox" (Gebauer \& Friedli, 2005). The theoretical analysis developed here enables us to explain the difference in outcomes because there are organizational factors that may moderate the relationship between servitization and outcomes (Yan et al., 2020). In addition, the different ways of measuring results may give rise to variations in the analysis of the relationship between servitization and performance (Shah et al., 2020). Zhang et al. (2019), for example, identify a non-linear relationship between servitization and financial performance, while Fang et al. (2008) conclude that an industrial firm's decision to provide services may have both positive and negative effects. Specifically, the effects that servitization has on firm performance may be positive only when the level of service sales attains critical mass (around $20 \%$ to $30 \%$ of the firm's overall turnover), ensuring that the services provided are strongly related to the firm's core manufacturing business.

The second most common research topic in the papers studied here involves capabilities $(16.13 \%)$. This subject has specifically been analysed mostly through theoretical approaches such as Resource-based theory (Coreynen et al., 2017; Hasselblatt, Huikkola, Kohtamäki \& Nickell, 2018; Huikkola \& Kohtamäki, 2017; Ulaga \& Reinartz, 2011), Contingency theory (Ceci \& Masini, 2011; Ceci \& Prencipe, 2008), and Resource dependence theory (Li, Zhu, Lin, Ma, \& Huang, 2015).

Studies such as those conducted by Ceci and Masini (2011) analyse the operational and dynamic capabilities required for servitization, calling upon manufacturers and customers to work together to create capabilities to enable service offerings and optimise service performance. Known examples of such capabilities in the context of servitization are 'hybrid offering sales', 'hybrid offering deployment' and 'service-related data processing and interpretation capabilities' (Ulaga \& Reinartz, 2011). Coreynen et al. (2017) and Kohtamäki et al. (2019) have focused on the capabilities required for developing digital servitization.

Third place corresponds to Business models, an approach that specifically features in $10.75 \%$ of the papers in our sample. This topic has been analysed mainly through boundary of the firm theories, such as Game theory (Nishino, Wang, Tsuji, Kageyama \& Ueda, 2012), Industrial organization theory (Kohtamäki et al., 2019), Resource-based theory (Kessler \& Stephan, 2013; Kohtamäki et al., 2019; Lütjen, Tietze \& Schultz, 2017), and Transaction cost theory (Bellandi \& Santini, 2019; Mont et al., 2006).

The servitization of the manufacturing sector involves the emergence of a new business model that is modifying the structure of many industries that opt for the provision of holistic solutions (Ceci \& Masini, 2011). In their approach to a successful servitization process, companies need to redesign their business model (Baines et al., 2009a). This literature review has identified different studies that analyse this aspect from different perspectives. For example, Nishino et al., (2012) define a 'platform-type product service system' as a comprehensive business model with a common platform on which service providers, consumers, and manufacturers mutually interact. Parida, Sjödin and Reim (2019) describe the impact that the digitalization undertaken by manufacturing firms has on their service business model (digital servitization). Kohtamäki et al. (2019) consider that business models in digital servitization should be viewed from an ecosystem perspective.

Fourth place corresponds to Supply Chain Management (SCM), which has been analysed through, among others, Contingency theory (Engelseth \& Jafari, 2018); Resource dependence theory (Shah et al., 2020), and Transaction cost theory (Boehmer et al., 2020; Lietke \& Boslau, 2007; Wiig, 2001).

SCM encompasses the efforts involved in delivering and producing products and services in the value chain (Vendrell-Herrero, Bustinza, Parry \& Georgantzis, 2017). Shah et al. (2020) contend that the focus on servitization encourages organizations to enhance internal, supplier, and customer integration, which in turn enhance 
servitization (basic and advanced service provision), specifically positing that servitization-oriented firms need to improve a specific dimension of their supply chain integration to reinforce a particular type of service provision.

Finally, there are two research topics that have appeared in $6.45 \%$ of the papers, namely Strategy and Sustainability.

Strategy has been analysed mainly through Resource dependence theory (Chang et al., 2019; Li et al., 2015); Contingency theory (Pleshko \& Heiens, 2011; Pleshko, Heiens \& Peev, 2014) and Game theory (Chang et al., 2019; Hsieh \& Yeh, 2018; Li, Ji, Chen \& Jiao, 2017; Wang, Zheng, Zhao \& Tian, 2019; Zhong, 2014).

Baines, Lightfoot, Peppard, Johnson, Tiwari, Shehab et al. (2009b) for example, have already highlighted the strategic importance of servitizing the manufacturing sector, analysing industrial firms' internal production and support operations to ensure the effective and efficient delivery of products and their closely associated services. Service-oriented manufacturing and integrated solutions have therefore emerged as a new strategy in corporate practice ( $\mathrm{Li}$ et al., 2015). The theoretical underpinnings analysed show that there are scholars that consider servitization to be a competitive-level strategy (Lee et al., 2016), in the sense that traditional manufacturing firms launch services to supplement their products as a market differentiation strategy (Raddats \& Easingwood, 2010. By contrast, other firms view it as a functional-level strategy; for example, Fang et al. (2008) evaluate the effectiveness of service transition strategies as a marketing approach. Zhong (2014) contends that product-service integration enables a firm to improve its overall turnover, whereby it should adopt appropriate income distribution strategies to promote its product-service integration.

Sustainability has been addressed through sundry approaches, such as Institutional theory (Stål \& Corvellec, 2018); Social practice theory (Retamal \& Schandl, 2018; Sousa-Zomer \& Miguel, 2016); Game theory (Arabi et al., 2018; Chang et al., 2019; Hezarkhani, 2017), and Resource-based theory (Leismann, Schmitt, Rohn \& Baedeker, 2013).

The importance of the launch of services by manufacturing firms may also be analysed from the perspective of environmental sustainability, which highlights the need to manage a product's lifecycle through the provision of different kinds of services. These theoretical approaches reveal that servitization is a suitable approach for achieving sustainability because of the potential PSS have to simultaneously deliver social well-being and economic prosperity (Sousa-Zomer \& Miguel, 2016). What's more, PSS provides a combination of products and services that may fulfil customers' expectations, offering an alternative to the purchase of an existing product or a new one (Leismann et al., 2013). Retamal and Schandl (2018) and Stål and Corvellec (2018) have analysed PSS (or servitization systems) as circular business models.

\section{Conclusions}

With a view to shedding some light on the increase in the number of publications on servitization, and faced with the need to improve the theories related to the servitization process itself, our findings provide an alternative theoretical lens by combining different approaches to account for the success of firms' transformation in this field.

We propose using a double theoretical lens by combining different theories to analyse different research topics, which include the following:

- There is no doubt about the importance of servitization in the manufacturing sector, although it remains to be seen whether it should be considered a strategy at competitive level or, by contrast, at functional level in the field of production and operations, as well as in terms of marketing. Resource dependence, Contingency, and Game theories may provide the appropriate frameworks for identifying different generic configurations of servitization strategies. There is a need for a further exploration of the strategic approach to servitization to discover whether or not it may be considered a functional strategy within a firm; for example, for the field of production and operations, or even for marketing.

- Resource-based and Contingency theories may also be applied to the analysis of the relationship between organizational aspects, servitization and performance. This is consistent with other prior studies, such as those conducted by Yan et al. (2020) and Ceci and Masini (2011). It would be expedient to propose models of fit between environmental and organizational variables, capabilities, and resources in order to identify 
the more profitable type of servitization model. This would help to explain how capabilities in servitization generate competitive advantage and the types of configurations of resources and processes they require. These theories might constitute the theoretical lens that best explains the service paradox.

- It would be expedient to analyse the earnings and costs linked to different levels of servitization from the perspective of Transaction cost and Resource-based theories (Zhang et al., 2019) to ensure industrial firms make the right decision when launching a servitization process. These analyses could be supplemented by the study of value co-creation.

- Different industries are now facing the major challenge of digitalization. The Internet of Things (IOT), smart data-based products and services, and technologies are forcing organizations to create wholly new business models focused on products and service-based approaches. Specifically, advances in information technology and digitalization are prompting new business models involving digital servitization. It would be convenient to identify the dynamic capabilities that need to be deployed in industries that are intensive in technology and R\&D, which would also lead to improvements in performance. These studies should be conducted within the theoretical framework of Resource-based and Resource dependence theories.

- In turn, concern for the environment and sustainability are topics that merit greater analysis, in the sense that servitization may feasibly be considered an enabler of sustainability. This finding is consistent with prior studies, such as the one by Díaz-Garrido et al. (2018). Nevertheless, sustainability will not be achieved solely through innovations in terms of the provision of services, as there is a need for additional research that considers sustainable consumption and demand with a view to introducing sustainable PPS that are profitable from an economic, environmental and social perspective. This may be readily argued through Social practice, Game and Resource-based theories.

- Dealings with customers and suppliers within SCM in industrial firms will require a far-reaching review of the internal and external supply and demand of goods and services to ensure the combination and acquisition of the resources and capabilities required for servitization, in line with the findings reported by Shah et al. (2020). These analyses should be framed within the lens of theoretical approaches such as Contingency theory, Resource dependence theory, and Transaction cost theory.

Our study makes a significant contribution to the state-of-the-art on the theory of servitization, specifically helping to analyse the theoretical lens that can better explain the subject of servitization in general, and its associated research topics in particular.

This study has several implications for the servitization literature. First, identifying the theoretical foundations that demostrate a great degree of scientific maturity of servitization-related research. Second, not only the thematic areas that may be of interest for future research have been identified, but also the theoretical foundations under which such research could be developed have been indicated.

The present study has several practical implications for managers who are engaged in servitization. It is expected that servitization can help industrial companies in undertaking the digital transformation of their businesses and in improving environmental sustainability.

Notwithstanding this contribution, our paper has certain limitations. Firstly, we have used only one database (SCOPUS) and the peer-reviewed papers featured in it. Some publications may therefore have been overlooked. Secondly, we have only considered papers written in English, whereby there may be other publications drafted in other languages, such as Chinese, Italian, French or German, for example.

\section{Declaration of Conflicting Interests}

The authors declared no potential conflicts of interest with respect to the research, authorship, and/or publication of this article.

\section{Funding}

The authors received no financial support for the research, authorship, and/or publication of this article. 


\section{References}

Arabi, M., Mansour, S., \& Shokouhyar, S. (2018). Optimizing a warranty-based sustainable product service system using game theory. International Journal of Sustainable Engineering, 11(5), 330-341. https://doi.org/10.1080/19397038.2017.1387187

Bacharach, S.B. (1989). Organizational Theories: Some Criteria for Evaluation. Academy of Management Review, 14(4), 496-515. https://doi.org/10.5465/amr.1989.4308374

Baines, T.S., Lightfoot, H.W., Benedettini, O., \& Kay, J.M. (2009a). The servitization of manufacturing: A review of literature and reflection on future challenges. Journal of Manufacturing Technology Management, 20(5), 547-567. https://doi.org/10.1108/17410380910960984

Baines, T.S., Lightfoot, H.W., Peppard, J., Johnson, M., Tiwari, A., Shehab, E. et al. (2009b). Towards an operations strategy for product-centric servitization. International Journal of Operations and Production Management, 29(5), 494-519. https://doi.org/10.1108/01443570910953603

Barney, J.B. (1991). Firm resources and sustained competitive advantage. Journal of Managament, 17(1), 99-120. https://doi.org/10.1177/014920639101700108

Bellandi, M., \& Santini, E. (2019). Territorial servitization and new local productive configurations: the case of the textile industrial district of Prato. Regional Studies, 53(3), 356-365. https://doi.org/10.1080/00343404.2018.1474193

Boehmer, J.H., Shukla, M., Kapletia, D., \& Tiwari, M.K. (2020). The impact of the Internet of Things (IoT) on servitization: an exploration of changing supply relationships. Production Planning and Control, 31(2-3), 203-219. https://doi.org/10.1080/09537287.2019.1631465

Callon, M., Courtial, J.P., \& Penan, H. (1993). Cienciometría. La medición de la actividad cientifica: de la bibliometría a la vigilancia tecnológica. Gijón: Trea, Ed.

Ceci, F., \& Masini, A. (2011). Balancing specialized and generic capabilities in the provision of integrated solutions. Industrial and Corporate Change, 20(1), 91-131. https://doi.org/10.1093/icc/dtq069

Ceci, F., \& Prencipe, A. (2008). Configuring capabilities for integrated solutions: Evidence from the IT sector. Industry and Innovation, 15(3), 277-296. https://doi.org/10.1080/13662710802040879

Chang, F., Zhou, G., Zhang, C., Xiao, Z., \& Wang, C. (2019). A service-oriented dynamic multi-level maintenance grouping strategy based on prediction information of multi-component systems. Journal of Manufacturing Systems, 53, 49-61. https://doi.org/10.1016/j.jmsy.2019.09.005

Child, J. (1975). Managerial and organizational factors associated with company performance-PartII. A contingency analysis. Journal of Management Studies, 12(1-2), 12-27. https://doi.org/10.1111/j.1467-6486.1975.tb00884.x

Coase, R.H. (1937). The Nature of the Firm. Economica, 4(16), 386-405. https://doi.org/10.1111/j.14680335.1937.tb00002.x

Colquitt, J.A., \& Zapata-Phelan, C.P. (2007). Trends in theory building and theory testing: A five-decade study of the Academy of Management Journal. Academy of Management Journal, 50(6), 1281-1303. https://doi.org/10.5465/AMJ.2007.28165855

Coreynen, W., Matthyssens, P., \& Van Bockhaven, W. (2017). Boosting servitization through digitization: Pathways and dynamic resource configurations for manufacturers. Industrial Marketing Management, 60, 42-53. https://doi.org/10.1016/j.indmarman.2016.04.012

Datta, P.P. (2020). Hidden costs in different stages of advanced services - A multi-actor perspective of performance based contracts. Journal of Business Research. https://doi.org/10.1016/j.jbusres.2020.03.036

Díaz-Garrido, E., Pinillos, M.J., Soriano-Pinar, I., \& García-Magro, C. (2018). Changes in the intellectual basis of servitization research: A dynamic analysis. Journal of Engineering and Technology Management, (June 2017), 1-14. https://doi.org/10.1016/j.jengtecman.2018.01.005

Drazin, R., \& Van de Ven, A.H. (1985). Alternative Forms of Fit in Contingency Theory. Administrative Science Quarterly, 30(4), 514. https://doi.org/10.2307/2392695 
Duncan, R.B. (1972). Characteristics of Organizational Environments and Perceived Environmental Uncertainty. Administrative Science Quarterly, 17(3), 313. https://doi.org/10.2307/2392145

Eloranta, V., \& Turunen, T. (2015). Seeking competitive advantage with service infusion: A systematic literature review. Journal of Service Management, 26(3), 394-425. https://doi.org/10.1108/JOSM-12-2013-0359

Engelseth, P., \& Jafari, H. (2018). Marketing complex product designs in the contemporary value chain. International Journal of Value Chain Management, 9(4), 311-329. https://doi.org/10.1504/IJVCM.2018.095259

Falagas, M.E., Pitsouni, E.I., Malietzis, G.A., \& Pappas, G. (2008). Comparison of PubMed, Scopus, Web of Science, and Google Scholar: strengths and weaknesses. The FASEB Journal, 22(2), 338-342. https://doi.org/10.1096/fj.07-94921sf

Fang, E., Palmatier, R. W., \& Steenkamp, J.-B.E.M. (2008). Effect of Service Transition Strategies on Firm Value. Journal of Marketing, 72(5), 1-14. https://doi.org/10.1509/jmkg.72.5.001

Forkmann, S., Henneberg, S.C., Witell, L., \& Kindström, D. (2017). Driver Configurations for Successful Service Infusion. Journal of Service Research, 20(3), 275-291. https://doi.org/10.1177/1094670517706160

Gebauer, H., \& Fleisch, E. (2007). An investigation of the relationship between behavioral processes, motivation, investments in the service business and service revenue. Industrial Marketing Management, 36(3), 337-348. https://doi.org/10.1016/j.indmarman.2005.09.005

Gebauer, H., \& Friedli, T. (2005). Behavioral implications of the transition process from products to services. Journal of Business and Industrial Marketing, 20(2), 70-78. https://doi.org/10.1108/08858620510583669

Geng, X., Chu, X., Xue, D., \& Zhang, Z. (2011). A systematic decision-making approach for the optimal productservice system planning. Expert Systems with Applications, 38(9), 11849-11858.

https://doi.org/10.1016/j.eswa.2011.03.075

Gioia, D.A., \& Pitre, E. (1990). Multiparadigm perspectives on theory building. Academy of Management Review, 15, 584-602. https://doi.org/10.5465/amr.1990.4310758

Gómez, C.G., \& Heredero, C.D.P. (2013). La gamificación y el enriquecimiento de las prácticas de innovación en la empresa: Un análisis de experiencias. Intangible Capital, 9(3), 800-822. https://doi.org/10.3926/ic.377

Gremyr, I., Löfberg, N., \& Witell, L. (2010). Service innovations in manufacturing firms. Managing Service Quality, 20(2), 161-175. https://doi.org/10.1108/09604521011027589

Hasselblatt, M., Huikkola, T., Kohtamäki, M., \& Nickell, D. (2018). Modeling manufacturer's capabilities for the Internet of Things. Journal of Business and Industrial Marketing, 33(6), 822-836. https://doi.org/10.1108/JBIM-11-20150225

Hezarkhani, B. (2017). Optimal design of uptime-guarantee contracts under IGFR valuations and convex costs. European Journal of Operational Research, 256(2), 556-566. https://doi.org/10.1016/j.ejor.2016.06.032

Hsieh, Y.H., \& Yeh, S.Y. (2018). Modeling dynamic service recovery strategies: a signaling game approach. Kybernetes, 47(5), 888-919. https://doi.org/10.1108/K-05-2017-0171

Huikkola, T., \& Kohtamäki, M. (2017). Solution providers' strategic capabilities. Journal of Business and Industrial Marketing, 32(5), 752-770. https://doi.org/10.1108/JBIM-11-2015-0213

Johnson, M.D., Herrmann, A., \& Bauer, H.H. (1999). The effects of price bundling on consumer evaluations of product offerings. International Journal of Research in Marketing, 16(2), 129-142. https://doi.org/10.1016/s01678116(99)00004-x

Kanninen, T., Penttinen, E., Tinnilä, M., \& Kaario, K. (2017). Exploring the dynamic capabilities required for servitization: The case process industry. Business Process Management Journal, 23(2), 226-247. https://doi.org/10.1108/BPMJ-03-2015-0036

Kessler, T., \& Stephan, M. (2013). Service transition in the automotive industry. International Journal of Automotive Technology and Management, 13(3), 237-256. https://doi.org/10.1504/IJATM.2013.054919 
Kohtamäki, M., Parida, V., Oghazi, P., Gebauer, H., \& Baines, T.S. (2019). Digital servitization business models in ecosystems: A theory of the firm. Journal of Business Research, 104, 380-392.

https://doi.org/10.1016/j.jbusres.2019.06.027

Kohtamäki, M., Partanen, J., Parida, V., \& Wincent, J. (2013). Non-linear relationship between industrial service offering and sales growth: The moderating role of network capabilities. Industrial Marketing Management, 42(8), 1374-1385. https://doi.org/10.1016/j.indmarman.2013.07.018

Lee, S., Yoo, S., \& Kim, D. (2016). When is servitization a profitable competitive strategy? International Journal of Production Economics, 173, 43-53. https://doi.org/10.1016/j.ijpe.2015.12.003

Leismann, K., Schmitt, M., Rohn, H., \& Baedeker, C. (2013). Collaborative consumption: Towards a resource-saving consumption culture. Resources, 2(3), 184-203. https://doi.org/10.3390/resources2030184

Li, A.Q., Kumar, M., Claes, B., \& Found, P. (2020). The state-of-the-art of the theory on Product-Service Systems. International Journal of Production Economics, 222(September 2019). https:/ / doi.org/10.1016/j.ijpe.2019.09.012

Li, H., Ji, Y., Chen, L., \& Jiao, R.J. (2017). Bi-Level Coordinated Configuration Optimization for Product-Service System Modular Design. IEEE Transactions on Systems, Man, and Cybernetics: Systems, 47(3), 537-554. https://doi.org/10.1109/TSMC.2015.2507407

Li, J.H., Zhu, W.J., Lin, L., Ma, L.Y., \& Huang, Q.B. (2015). Manufacturer-user dependence, relationship learning and manufacturer servitisation in China. International Journal of Technology, Policy and Management, 15(4), 311-312. https://doi.org/10.1504/IJTPM.2015.072792

Lietke, B., \& Boslau, M. (2007). Exploring the transaction dimensions of supply chain management. International Journal of Networking and Virtual Organisations, 4(2), 163-179. https:/ / doi.org/10.1504/IJNVO.2007.013541

Lütjen, H., Tietze, F., \& Schultz, C. (2017). Service transitions of product-centric firms: An explorative study of service transition stages and barriers in Germany's energy market. International Journal of Production Economics, 192, 106-119. https://doi.org/10.1016/j.ijpe.2017.03.021

Martín-Peña, M.L., Pinillos, M.J., \& Reyes, L.E. (2017). The intellectual basis of servitization: A bibliometric analysis. Journal of Engineering and Technology Management - JET-M, 43, 83-97. https://doi.org/10.1016/j.jengtecman.2017.01.005

Mont, O., Dalhammar, C., \& Jacobsson, N. (2006). A new business model for baby prams based on leasing and product remanufacturing. Journal of Cleaner Production, 14(17), 1509-1518.

https://doi.org/10.1016/j.jclepro.2006.01.024

Neu, W., \& Brown, S. (2005). Forming successful business-to-business services in goods-dominant firms. Journal of Service Research, 8(1), 3-17. https://doi.org/10.1177/1094670505276619

Nishino, N., Wang, S., Tsuji, N., Kageyama, K., \& Ueda, K. (2012). Categorization and mechanism of platformtype product-service systems in manufacturing. CIRP Annals - Manufacturing Technology, 61(1), 391-394. https://doi.org/10.1016/j.cirp.2012.03.053

Oliva, R., \& Kallenberg, R. (2003). Managing the transition from products to services. International Journal of Service Industry Management, 14(2), 160-172. https://doi.org/10.1108/09564230310474138

Oliveira, P., \& Roth, A.V. (2012, February). Service orientation: The derivation of underlying constructs and measures. International Journal of Operations and Production Management, 32, 156-190. https://doi.org/10.1108/01443571211208614

Parida, V., Sjödin, D., \& Reim, W. (2019, January 14). Reviewing literature on digitalization, business model innovation, and sustainable industry: Past achievements and future promises. Sustainability (Switzerland), $11,391$. https://doi.org/10.3390/su11020391

Pleshko, L.P., \& Heiens, R.A. (2011). A contingency theory approach to market orientation and related marketing strategy concepts: Does fit relate to share performance? Academy of Banking Studies Journal, 10(1), 119-133.

Pleshko, L.P., Heiens, R.A., \& Peev, P. (2014). The impact of strategic consistency on market share and ROA. International Journal of Bank Marketing, 32(3), 176-193. https://doi.org/10.1108/IJBM-06-2013-0057 
Rabetino, R., Harmsen, W., Kohtamäki, M., \& Sihvonen, J. (2018). Structuring servitization-related research. International Journal of Operations and Production Management, 38, 350-371. https://doi.org/10.1108/IJOPM-03-2017-0175

Raddats, C., Burton, J., \& Ashman, R. (2015). Resource configurations for services success in manufacturing companies. Journal of Service Management, 26(1), 97-116. https://doi.org/10.1108/JOSM-12-2012-0278

Raddats, C., \& Easingwood, C. (2010). Services growth options for B2B product-centric businesses. Industrial Marketing Management, 39(8), 1334-1345. https://doi.org/10.1016/j.indmarman.2010.03.002

Raddats, C., Kowalkowski, C., Benedettini, O., Burton, J., \& Gebauer, H. (2019). Servitization: A contemporary thematic review of four major research streams. Industrial Marketing Management, 83, 207-223. https://doi.org/10.1016/j.indmarman.2019.03.015

Ramos-Rodríguez, A.R., \& Ruiz-Navarro, J. (2004). Changes in the intellectual structure of strategic management research: a bibliometric study of theStrategic Management Journal, 1980-2000. Strategic Management Journal, 25(10), 981-1004. https://doi.org/10.1002/smj.397

Retamal, M., \& Schandl, H. (2018). Dirty Laundry in Manila: Comparing Resource Consumption Practices for Individual and Shared Laundering. Journal of Industrial Ecology, 22(6), 1389-1401. https://doi.org/10.1111/jiec.12696

Rumelt, R.P. (1984). Towards a strategic theory of the firm. Competitive Strategic Management, 26(3), 556-570.

Shah, S.A.A., Jajja, M.S.S., Chatha, K.A., \& Farooq, S. (2020). Servitization and supply chain integration: An empirical analysis. International Journal of Production Economics, 229. https://doi.org/10.1016/j.ijpe.2020.107765

Song, D.W., \& Panayides, P.M. (2002). A conceptual application of cooperative game theory to liner shipping strategic alliances. Maritime Policy and Management, 29(3), 285-301. https://doi.org/10.1080/03088830210132632

Sousa-Zomer, T.T., \& Miguel, P.A.C. (2016). Exploring the consumption side of sustainable product-service systems (PSS): An empirical study and insights for PSS sustainable design. CIRP Journal of Manufacturing Science and Technology, 15, 74-81. https://doi.org/10.1016/j.cirpj.2016.04.004

Stål, H.I., \& Corvellec, H. (2018). A decoupling perspective on circular business model implementation: Illustrations from Swedish apparel. Journal of Cleaner Production, 171, 630-643. https://doi.org/10.1016/j.jclepro.2017.09.249

Storbacka, K. (2011). A solution business model: Capabilities and management practices for integrated solutions. Industrial Marketing Management, 40(5), 699-711. https://doi.org/10.1016/j.indmarman.2011.05.003

Tranfield, D., Denyer, D., \& Smart, P. (2003). Towards a methodology for developing evidence-informed management knowledge by means of systematic review. British Journal of Management, 14(3), 207-222. https://doi.org/10.1111/1467-8551.00375

Tukker, A. (2015, June 15). Product services for a resource-efficient and circular economy - A review. Journal of Cleaner Production, 97, 76-91. https://doi.org/10.1016/j.jclepro.2013.11.049

Tuli, K.R., Kohli, A.K., \& Bharadwaj, S.G. (2007). Rethinking Customer Solutions: From Product Bundles to Relational Processes. Journal of Marketing, 71(3), 1-17. https://doi.org/10.1509/jmkg.71.3.001

Ulaga, W., \& Reinartz, W.J. (2011). Hybrid offerings: How manufacturing firms combine goods and services successfully. Journal of Marketing, 75(6), 5-23. https://doi.org/10.1509/jm.09.0395

Vandermerwe, S., \& Rada, J. (1988). Servitization of business: adding value by adding service. In: European Management Journal, 6(4), 314-320. https://doi.org/10.1016/0263-2373(88)90033-3

Vendrell-Herrero, F., Bustinza, O.F., Parry, G., \& Georgantzis, N. (2017). Servitization, digitization and supply chain interdependency. Industrial Marketing Management, 60, 69-81. https://doi.org/10.1016/j.indmarman.2016.06.013

Venkatraman, N. (1989). The Concept of Fit in Strategy Research: Toward Verbal and Statistical Correspondence. Academy of Management Review, 14(3), 423-444. https://doi.org/10.5465/amr.1989.4279078

Visnjic, I., \& Van Looy, B. (2013). Successfully Implementing a Service Business Model in a Manufacturing Firm. In Cambridge Service Alliance. Available at: www.cambridgeservicealliance.org 
Von Neumann, J., Morgenstern, O., \& Kuhn, H.W. (1944). Theory of Games and Economic Behavior. Princeton, NJ: Princeton University Press.

Walker, H., Chicksand, D., Radnor, Z., \& Watson, G. (2015). Theoretical perspectives in operations management: An analysis of the literature. International Journal of Operations and Production Management, 35(8), 1182-1206. https://doi.org/10.1108/IJOPM-02-2014-0089

Wallin, J., Parida, V., \& Isaksson, O. (2015). Understanding product-service system innovation capabilities development for manufacturing companies. Journal of Manufacturing Technology Management, 26(5), 763-787. https://doi.org/10.1108/JMTM-05-2013-0055

Wang, W., Lai, K.H., \& Shou, Y. (2018). The impact of servitization on firm performance: a meta-analysis. International Journal of Operations and Production Management, 38, 1562-1588. https://doi.org/10.1108/IJOPM-04-20170204

Wang, Z., Zheng, L., Zhao, T., \& Tian, J. (2019). Mitigation strategies for overuse of Chinese bikesharing systems based on game theory analyses of three generations worldwide. Journal of Cleaner Production, 227, 447-456. https://doi.org/10.1016/j.jclepro.2019.04.100

Wernerfelt, B. (1984). A resource-Based View of the firm. Strategic Management Journal, 5(2), 171-178. https://doi.org/10.1002/smj.4250050207

Wiig, A. (2001). Supply chain management in the oil industry: The Angolan case. Working Paper-Chr. Michelsen Institute, 6, 1-37. Retrieved from www.cmi.no

Williamson, O.E. (1977). Markets and hierarchies. Challange, 20. Available at: https://books.google.es/books?hl=es\&lr=\&id=pg-

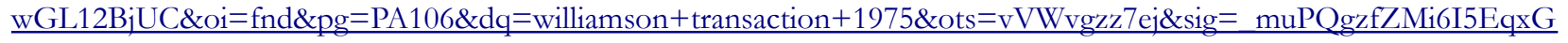
$\underline{\text { LvL4JvpvY }}$

Wise, R., \& Baumgartner, P. (1999). Go Downstream: The New Profit Imperative in Manufacturing. Harvard Business Review, 77(5), 133-141.

Yan, K., Li, G., \& Cheng, T.C.E. (2020). The impact of service-oriented organizational design factors on firm performance: The moderating role of service-oriented corporate culture. International Journal of Production Economics, 228, 107745. https://doi.org/10.1016/j.ijpe.2020.107745

Zhang, Y., Wang, L., Gao, J., \& Li, X. (2019). Servitization and business performance: the moderating effects of environmental uncertainty. Journal of Business and Industrial Marketing, 35(5), 803-815.

https://doi.org/10.1108/JBIM-03-2019-0123

Zhong, H. (2014). Game analysis of product-service integration. Journal of Industrial Engineering and Management, 7(5), 1447-1467. https://doi.org/10.3926/jiem.1221 
Appendix A. Papers analysed.

PAPERS
ORGANIZATIONAL BOUNDARY THEORY
Bureaucracy theory
Contingency theory (10)
Balancing specialized and generic capabilities in the
provision of integrated solutions
Theoretical perspectives in operations management: An
analysis of the literature
Configuring capabilities for integrated solutions: Evidence
from the IT sector
The impact of strategic consistency on market share and
ROA
A contingency theory approach to market orientation and
related marketing strategy concepts: Does fit relate to
share performance?

Service delivery system design for risk management in sharing-based product service systems: a customeroriented approach

Specialised capabilities in integrated solutions: The role of fit

Successful business models for service centres: an empirical analysis

The impact of service-oriented organizational design factors on firm performance: The moderating role of serviceoriented corporate culture

Marketing complex product designs in the contemporary value chain

Elements administration

Ecological theory (1)

Ecosystem evolution mechanism of manufacturing service system driven by service providers

Fatalism

Humans relations theory

Institutional theory (3)

A decoupling perspective on circular business mode implementation: Illustrations from Swedish apparel

Management accounting change and the implementation of gfmis: A Jordanian case study

Alsarari, N.M., ElAziz

17 Youssef, M.A.

How institutional pressures and systems characteristics shape customer acceptance of smart product-service systems

\section{linear programming (14)}

Optimization of a Distributed Cogeneration System with solar district heating

Capturing dynamics in integrated supply chain management

An exact algorithm for the integrated planning of berth

allocation and quay crane assignment

YEAR

AUTHORS

2011 Ceci, F. Masini, A 2015 Radnor, Z., Watson, G.

2008 Ceci, F. Prencipe, A. 2014 Peev, P. 2017 Tang, R., Pan, X. 2020 Kropp, E., Totzek, D.

2014
KEYWORDS

METHODOLOGY RESEARCH THEME Walker, H., Chicksand, D.

Pleshko, L.P., Heiens, R.A.,

2011 Pleshko, L.P., Heiens, R.A.

Firm size, industrial performance, industrial structure, information

technology, model test

Operations management, Literature review, Theory

Capabilities, integrated solutions, IT sector, contingency theory, resourcebased view

Marketing strategy, Strategic fit, Firm performance, Credit unions, Miles and Snow typology, Porter typology

Survey

Strategy

Marketing strategy, Strategic fit, Firm performance, Credit unions, Miles and Snow typology, Porter typology

Strategy

Product-service systems (PSS), Risk

management, Service delivery system

Hazée, S., Van Vaerenbergh, design, Servitization, Sharing economy, 2020 Y., Delcourt, C., Kabadayi, S

Trust

Survey

Contingency theory; integrated solutions; IT sector; capabilities

Value co-creation, business models Organizational aspects, business

Business model, Medium-heavy commercial vehicle industry, Service centres, Servitization, Top performer Servitization, Organizational change, Organizational design factors, Culture, Firm perfomance models

Postponement, customer value, supply timing, Alderson, transvection, servitisa tion

Manufacturing service system; service Zhang, W., Shi, Y., Yang, M. providers; producer services; ecological evolution; predatorprey model

Circular business models, circular economy, decoupling, sustainable business models, institutional theory, product-service-systems Institutional theory, Government Financial Management Information Systems, Management accounting change

Adoption of innovations, Business-tobusiness marketing, Digitization, Institutional theory, Internet of things, Product-service systems

Digitalization consumer behavior

2008 Puigjaner, L., Laínez, J.M.

Supply chain management; Predictive

SCM, Strategy, performance (creation value) 
A systematic decision-making approach for the optimal product-service system planning

A utility-driven approach to supplier evaluation and selection: Empirical validation of an integrated solution framework

Aircraft maintenance, routing, and crew scheduling

planning for airlines with a single fleet and a single

maintenance and crew base

Integrated stochastic optimization approaches for tactical scheduling of trains and railway infrastructure maintenance Air traffic optimization models for aircraft delay and travel time minimization in terminal control areas

Module configuration approach for product service system design driven by customer requirements

A specialized column generation approach for a vehicle

routing problem with demand allocation

Application driven inverse type constraint satisfaction problems

An initial load-based green software defined network

Centralized visual based navigation and control of a swarm of satellites for on-orbit servicing

Sustainable water supply systems for the islands: The integration with the energy problem

Organizational behavior (6)

Theoretical perspectives in operations management: An

analysis of the literature

Towards a model of governance in complex (productservice) inter-organizational systems

An empirical study on the influences on the acquisition of enterprise software decisions: A practitioner's perspective

Transforming cross-cultural conflict into collaboration: The integration of western and eastern values

Computerized Immediate Feedback Increases Product

Recall Efficiency Due to Interlocking Contingencies in Food

Manufacturing

The effect of organizational citizenship behaviors on the

success of enterprise resource planning (ERP) information systems

Resource dependence (4)

A service-oriented dynamic multi-level maintenance grouping strategy based on prediction information of multicomponent systems

Manufacturer-user dependence, relationship learning and manufacturer servitisation in China

Servitization and supply chain integration: An empirical analysis
Product-service system (PSS),

Engineering characteristics (EC), Fuzzy

Geng, X. Chu, X., Xue, D. pairwise comparison, Kano model, Non2011 Zhang, $Z$.

linear programming

Case study

Performance

2016

2014

2019

2015

Customer requirements, Quality

function deployment, Product service Concpetual, Consumer behavior.

2016 Geng, X. Xu, S. Ye, C.

system

Theoretical analysis PSS, Quality

2017

2017

2020

2020

Walker, H., Chicksand, D., Operations management, theory,

Conceptual,

literature review literature review Theories

Product-Service Systems, Inter-

organizational Governance, Contracts,

2010 Roehrich, J.K., Lewis, M.A.

Trust, Complexity

Organizational

Computer software, Purchasing,

Palanisamy, R., Verville, J., Decision making, Organizational 2010 Bernadas, C., Taskin, N. behavior

Survey

2018

2017

2014

Product-service-system, Serviceoriented maintenance, Maintenance strategy, Grouping maintenance,

Chang, F. Zhou, G. Zhang, C., Predictive maintenance, Dynamic 2019 Xiao, Z, Wang, C.

rolling horizon
Conceptual, case Strategy

study (maintenence)
Joint dependence, dependence

advantage, relationship

learning, manufacturer

servitisation, resource dependence

theory, service-oriented

manufacturing, manufacturer-user

Li, J.H., Zhu, W.J., Lin, L., Ma, dependence, China, cooperation, com munication, value creation, joint action Survey

Servitization, Supply chain integration,

Firm performance, Empirical research,

Shah, S.A.A. Jajja, M.S.S. International manufacturing strategy 2020 Chatha, K.A., Faroog, S. survey
Strategy,

capabilities

Performance 
Construct Outsourcing Vendor Selection Criteria for Business Intelligence

Scientific management (5)

Toward a ubiquitous personalized daily-life activity recommendation service with contextual information: $A$ services science perspective

Services science to be taught at NC state

System convergence in the crafting and execution of a services directed strategy: A technology perspective Services management in highly competitive contexts of tumultuous change

Toward a ubiquitous personalized daily-life activity recommendation service with contextual information: A services science perspective Social practice theory (4)

The role of values in collaborative consumption: Insights from a product-service system for lending and borrowing in the UK

Piscicelli, L., Cooper, T.,

Collaborative consumption, Proenvironmental behavior change, Product-service systems, Social

practice theory, Social psychology, Values

Sharing economy, Social practice

Collaborative consumption practices in Southeast Asian cities: Prospects for growth and sustainability

Dirty Laundry in Manila: Comparing Resource Consumption Practices for Individual and Shared Laundering

Exploring the consumption side of sustainable productservice systems (PSS): An empirical study and insights for PSS sustainable design 2015 Fisher, $\mathrm{T}$.

2019 Retamal, M
2018 Retamal, M., Schandl, H.

Sousa-Zomer, T.T., Miguel, $\quad$ Sustainability, Consumption, Practice 2016 P.A.C. theory, Product-service systems, Emerging economies

Developing countries, households, industrial ecology, product-service system (PSS), social practices, sustainable consumption theory, Sustainable design
Business intelligence, outsourcing vendor, selection criteria, modified

Chang, C.-Y., Yang, J.-W. Wu, Delphi method, analytic hierarchy Método Delphi (13 2019 M.-C process

experts)

SCM, Performance

Wang, C.-Y., Wu, Y.-H., Chou, Service innovation, service 2010 S.-C.T.

productivity, service design

Service design, management, business

2006 Allen, S. G., Mugge, P. strategy

Case study

Flexibility, quatlity Strategy, Value cocreation Sustainability

\section{BOUNDARY OF THE FIRM THEORY} Agency theory (3)

Multitask agency, modular architecture, and task disaggregation in SaaS

Mitigating adverse customer behaviour for productservice system provision: An agency theory perspective

Hidden costs in different stages of advanced services - A multi-actor perspective of performance based contracts Game theory (20)

A module-based service model for mass customization: Service family design

When is servitization a profitable competitive strategy?

Bi-Level Coordinated Configuration Optimization for Product-Service System Modular Design

Categorization and mechanism of platform-type productservice systems in manufacturing
Endogenous matching, information technology, modularity, multitask Susarla, A., Barua, A., agency, outsourcing, service science, 2010 Whinston, A.B. services

Product-service systems (PSS), Agency Reim, W., Sjödin, D., Parida, theory, Trust, Adverse behavior, 2018 V

Agency mechanisms, Servitization

Hidden costs, Performance based contracts, Case based research, Servitization, Multi actor systems,

2020 Datta, P.P.

Engagement, S-D logic, Agency theory Case study

Performance (hidden cost)

Coalitional game, mass customization,

Moon, S.K., Shu, J., Simpson, module-based service model, service 2011 T.W., Kumara, S.R.T.

family and platform design Servitization, Channel competition, Game theory

Case study

Business models, innovation Strategy, performance

Bi-level programming, configuration design optimization, genetic programming, modular design, product- Case study, 2017 Li, H,. Ji, Y., Chen, L., Jiao, R.J. service systems (PSSs) conceptual Nishino, N., Wang, S., Tsuji, Service, Decision making, Business 2012 N., Kageyama, K., Ueda, K. model
Concpetual,

Theoretical analysis Business models 
Costing-based coordination between mt-iPSS customer and providers for job shop production using game theory

The gamification and the enrichment of innovation practices in the firm: An analysis of experiences

Optimal design of uptime-guarantee contracts under IGFR valuations and convex costs

Optimizing a warranty-based sustainable product service system using game theory

Game analysis about incentive of information sharing in product servitization supply chain

A service-oriented multi-player maintenance grouping strategy for complex multi-component system based on game theory

Mitigation strategies for overuse of Chinese bikesharing systems based on game theory analyses of three generations worldwide

Manufacturing service order allocation in the context of social manufacturing based on Stackelberg game

Modeling dynamic service recovery strategies: a signaling game approach

Game analysis of product-service integration

Analysis of membership-type service in manufacturing

using integrating approach with economic experiments and

multi-agent simulation

A Bayesian network approach for cybersecurity ris assessment implementing and extending the FAIR model

A systematical analysis on the dynamic pricing strategies and optimization methods for energy trading in smart grids Execution quality and chargeback penalties in retail supply chains

A scheme design of cloud + end technology in demand side management

Research on the strategy of manufacturing enterprise carrying out service in full life cycle based on game theory Industrial organization (5)

Digital servitization business models in ecosystems: A theory of the firm

Treatment of olive oil waste waters

A knowledge graph-Aided concept-Knowledge approach for evolutionary smart product-Service systemdevelopment

$\mathrm{CO} 2$ reduction through digital transformation in longhaul transportation: Institutional entrepreneurship to unlock product-service system innovation
Product service systems; operational

research; job shop scheduling

Stackelberg game; coordination

decision

Case study

CRM

Gamification, Business strategy,

Innovation 2.0, Gameplay, Value co-

2013 Gómez, C.G., Heredero, C.P. creation, Games theory, Servitization Revenue management, Pricing, Game theory, Maintenance, Contracts,

Servitization

Conceptual

Value co-creation

performance

Performance,

2017 Hezarkhani, B.

End of life management; game theory;

2018 Arabi, M., Mansour, S

stackelberg; sustainability; warranty

Servitization, Suppy Chain, Game

2014 He, Z., Chen, J., Yao, S

theory

sustainability

Performance,

sustainability

Smart product service system,

Maintenance grouping strategy,

Performance-based maintenance,

Chang, F., Zhou, G., Cheng, Proactive services, Stackelberg-Nash game

Chinese bikesharing programs,

2019 W., Zhang, C., Tian, C.

Wang, Z., Zheng, L., Zhao, T., Overuse, Game theory, Management 2019 Tian, J

modes

Case study Strategy, SCM

Strategy,

performance,

sustainability

Stragegy,

maintenance

2019 Guo, W., Jiang, P.

Strategy, Service failure, Service

recovery, Game theory, Signalling

game

Case stud

Strategy, consumer

2018 Hsieh, Y.-H., Yeh, S.-Y.

Game theory, product-service

2014 Zhong, $\mathrm{H}$.

integration, shapley value, servitization Conceptua

Strategy,

organizational

aspects

Service engineering, multi-agent

simulation, lifestyle, equilibrium

Performance, $\mathrm{hr}$,

2014 Nishino, N., Okida, K.

analysis, service ecosystem

Survey

consumer beahavior

Jia, Y.-F., Miao, R. Cao, J.-T. Product service systems; Game theory, 2012 Wang, L.-Y. Jiang, Z.-B. Product life cycle

Others (simulation) Consumer behavior

Digitalization, Industry 4.0, Ecosystems, Digital servitization, Product-service

Kohtamäki, M., Parida, V., systems (PSS), Firm boundaries,

Ozhazi, P., Gebauer, H., Business model innovation, Platforms 2019 Baines, $T$.

and sustainability

Business models, strategy, industry 4.0

1986

Concept generation, Conceptual design, Concept-knowledge model, Creativity, Knowledge evolution,

Li, X., Chen, C., Zheng, P., Knowledge graph, Smart 2020 Wang, Z., Jiang, Z., Jiang, Z. product-service system Digital technology value, Digital Case study fexibility transformation, Ecological sustainability, Industrial entrepreneurship, Institutional 2020 Haftor, D.M., Climent, R.C entrepreneurship, Servitization 
Identification the intangibles arising from investments in prevention of occupational risks and their perception in smes. Implications in the service sector and the servitization

Resource-based (31)

Hybrid offerings: How manufacturing firms combine goods and services successfully

Effect of service transition strategies on firm value

Services growth options for B2B product-centric businesses

Boosting servitization through digitization: Pathways and dynamic resource configurations for manufacturers

Collaborative consumption: Towards a resource-saving consumption culture

Transitioning from product to service-led growth in manufacturing firms: Emergent challenges in selecting and managing the industrial sales force

Seeking competitive advantage with service infusion: A systematic literature review

Balancing specialized and generic capabilities in the provision of integrated solutions

Service innovation and new product performance: The influence of market-linking capabilities and market turbulence

Resource configurations for services success in

manufacturing companies

Theoretical perspectives in operations management: An analysis of the literature

Configuring capabilities for integrated solutions: Evidence from the IT sector

Understanding product-service system innovation capabilities development for manufacturing companies

Are my symptoms serious Dr Google? A resourcebased typology of value co-destruction in online self-diagnosis

Assessing transformational change from institutionalising digital capabilities on implementation and development of ProductService Systems: Learnings from the maritime industry

Solution providers' strategic capabilities Service transitions of product-centric firms: An explorative study of service transition stages and barriers in Germany's energy market

Modeling manufacturer's capabilities for the Internet of Things 2014 Rodríguez, A.
Cortés, M., Gragera, E., 2017 McAloone, T.C. 2017 C
Intangibles, prevención, valoración, rentabilidad, servitización Survey

Capabilities, performance
2011 Ulaga, W., Reinartz, W.J.

Fang, E., Palmatier, R.W.

Hybrid offerings, service transition strategies, resource-based view, business-to-business services, service classification, positional advantage

Service ratio, solution selling, service

transition strategies, Tobin's q, resource-based view, firm value

Product-centric, services, product2010 Raddats, C., Easingwood, C. attached, operations, servitization Servitization, Digitization, Value Coreynen, W., Matthyssens, innovation, Manufacturing companies, 2017 P., Van Bockhaven, W. SME

Collaborative consumption; resource efficiency; resource saving potential; rebound effects; product sharing; service; product service systems;

Leismann, K., Schmitt, M., $\quad$ ownership-substituting; services; sustainable consumption patterns Service transition strategies, Resource-

based view, Business-to-business services, Goods-centric sales force, Services sales force
Servitization, Dynamic capabilities, Servitization, Dynamic capabilities,
Competitive advantage, Resourcebased view, Relational view, Service infusion

Firm size, industrial performance, industrial structure, information technology, model test

Case study, survey strategy

Survey

Performance,

Survey

strategy

Capabilities,

strategy,

Survey performance

Digitalization,

Case study capabilities

Sustainability, flexibility

Concpetual,

Theoretical analysis Theories

Capabilities,

organizational

aspects,

Survey performance

Market-linking capability, Market

turbulence, New product performance,

Servitization service innovation

Capabilities, manufacturer, resource

configuration, service infusion,

servitization

Survey

Innovation

Raddats, C., Burton, J.,

2015 Ashman, R.

Operations management, theory,

Survey

Capabilities

literature review

Conceptual,

literature review Theories

Capability, Aerospace industry, Process

2008 Ceci, F. Prencipe, A.

$\begin{array}{lll}\text { Wallin, J. Parida, V., Isaksson, view, Product-service systems, } & & \text { Capabilities, } \\ \text { O. } & \text { Routines } & \text { Case study }\end{array}$

$\begin{array}{lll}\begin{array}{l}\text { Wallin, J. Parida, V., Isaksson, } \\ \text { o. view, Product-service systems, } \\ \text { Routines }\end{array} & \begin{array}{l}\text { Capabilities, } \\ \text { innovation }\end{array}\end{array}$

Pagoropoulos, A., Maier, A., Product-Service Systems, Digitization,

Customer, Maritime industry Solution business, solutions, strategic capability, resource-based view, 2017 Huikkola, T., Kohtamäki, M. servitization

Action research Capabilities

Survey

Performance, capabilities

Lütjen, H., Tietze, F., Schultz, Service transition; servitization; service innovation; barriers; energy utilities

Internet of Things, Industrial Internet,

Hasselblatt, M., Huikkola, T., servitization, resource-based view,

2018 Kohtamäki, M., Nickell, D. Business Intelligence, digitalization

Business models,

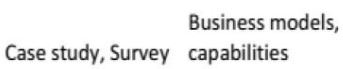

Case study, Survey $\quad 4.0$, Capabilities 


Innovative product development in hotel operations
Digital servitization business models in ecosystems: A
theory of the firm
Service transition in the automotive industry
Exploring the dynamic capabilities required for
servitization: The case process industry
Contemporary perspectives on the strategic role of
information in internet of things-driven industrial services
Allocation of composite mode on-orbit service resource
based on improved DQN

Servitization and business performance: the moderating effects of environmental uncertainty

Combat resource two-stage virtualization method in cloud cooperation

The transformation mechanism of servitisation in China: A resource-based perspective

An optimal configuration method of multi-level manufacturing resources based on community evolution for social manufacturing

Exploring the prot model of servitising manufacturers: A resource-based perspective The impact of service-oriented organizational design factors on firm performance: The moderating role of serviceoriented corporate culture

2006 Frehse, J.

Product

development, innovation, hotel

industry, hotel operations, resource-

based view

Digitalization, Industry 4.0, Ecosystems,

Digital servitization, Product-service

Kohtamäki, M., Parida, V., systems (PSS), Firm boundaries,

Ozhazi, P., Gebauer, H.,

Business model innovation, Platforms

and sustainability

service transition, automotive

industry, mechanical

engineering, diversification, customer

2013 Kessler, T., Stephan, M. integration, technological change

Kanninen, T., Penttinen, E., Servitization, Resource-based view, 2017 Tinnilä, M., Kaario, K.

\section{Capabilities, Process industry}

Servitization, Strategy, Resource-base

Turunen, T., Eloranta, V.,

view, Industrial services, loT, Service

infusion

Business models,

capabilities

Business models,

Conceptual, theories,

Theoretical analysis digitalization

Case study

Business models

Case study,

conceptual Business models

Organizational

Case study, survey aspects, Flexibility

Business performance, servitization,

Zhang, Y. Wang, L., Gao, J., Li, enviromental uncertainty, adjustment $2019 \mathrm{X}$.

cost, coordination cost

Survey

Performance

2018 Sun, H. Zhang, A., Gao, F.

Case study, China, resource-based

theory, resource

2017 Li, J. Lin, L. Ma, L.

management, servitisation

Case study

Capabilities

Social manufacturing, Resource

Zhang, Y., Zhang, D. Wang, Z., configuration, Dynamic community, 2020 Qian, C.

Multi-level Optimization

Organizational

Case study, Human resource, Profit model, Resource-based view,

2020 Li, J., Lin, L., Zhang, T.

Servitisation, Technology resource

Servitization, Organizational change,

Organizational design factors, Culture,

2020 Yan, K. Li, G., Cheng, T.C.E

Firm perfomance

Case study aspects

Flexibility

Organizational

aspects,

Survey performance

Business intelligence, outsourcing

vendor, selection criteria, modified

Construct Outsourcing Vendor Selection Criteria for

Business Intelligence

Chang, C.-Y., Yang, J.-W. Wu, Delphi method, analytic hierarchy

Transaction cost (11)

2019 M.-C

process

Delphy

Performance

Product-service systems; Leasing;

Mont, O., Dalhammar, C., Remanufacturing; Prams; Durable

products; Eco-design

product remanufacturing

2006 Jacobsson, N.

Vertical integration in supply chains: Driving forces and consequences for a manufacturer's downstream integration

2012 Guan, W. Rehme, J.

Vertical integration, Supply chain

integration, Downstream integration,

Building materials, Retailing,

Merchanting, Vertical marketing,

Sweden

Service science, service

quality, productivity, digital

connections, enterprise

engineering, cyber-

infrastructure, production

function, scaling, extended

enterprises, service cycle

digital connections scaling mode

2009 Cheng, Hsu., Spohrer, J.C.

imes, transaction costs

Digitalization, Industry 4.0, Ecosystems,

Digital servitization, Product-service

Kohtamäki, M., Parida, V., $\quad$ systems (PSS), Firm boundaries,

Ozhazi, $P_{\text {. }}$ Gebauer, H., Business model innovation, Platforms

Digital servitization business models in ecosystems: A

theory of the firm

2019 Baines, $\mathrm{T}$

$\begin{array}{ll} & \text { Business models, } \\ \text { Conceptual, theories, }\end{array}$

Theoretical analysis digitalization 
Territorial servitization and new local productive configurations: the case of the textile industrial district of Prato

Transition to circular economy on firm level: Barrier identification and prioritization along the value chain

Servitization and business performance: the moderating effects of environmental uncertainty

Exploring the transaction dimensions of supply chain management

The impact of the Internet of Things (loT) on servitization: an exploration of changing supply relationships Construct Outsourcing Vendor Selection Criteria for Business Intelligence

Supply chain management in the oil industry: The Angolan case

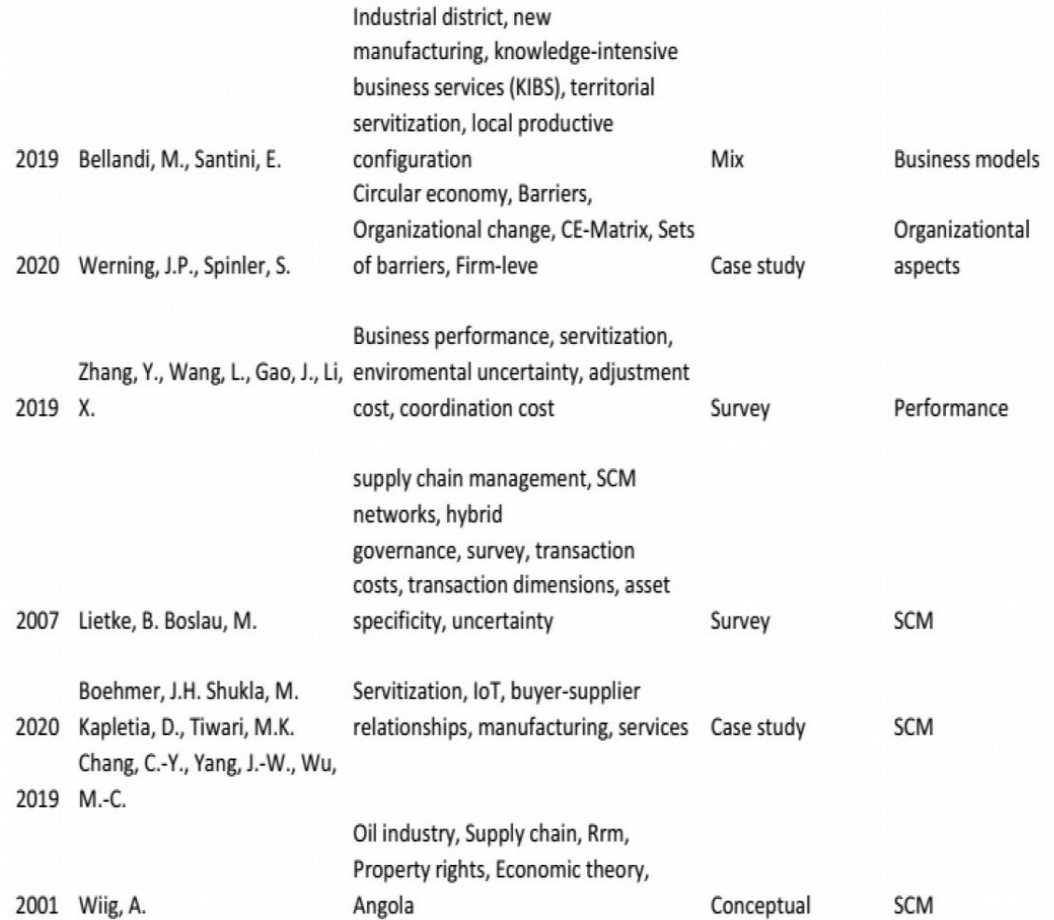

Journal of Industrial Engineering and Management, 2021 (www.jiem.org)

\section{(C) $(1) \circledast$}

Article's contents are provided on an Attribution-Non Commercial 4.0 Creative commons International License. Readers are allowed to copy, distribute and communicate article's contents, provided the author's and Journal of Industrial Engineering and Management's names are included. It must not be used for commercial purposes. To see the complete license contents, please visit https://creativecommons.org/licenses/by-nc/4.0/. 